\title{
A Comparative Study of the Effect of Melatonin Versus Vitamin C on Aged Labial Tissues in Albino Rats
}

\author{
Rania Ahmed Awwad, Marwa Mohamed Abd ElHameed and Dina Mohamed Abdel khalik
}

Department of Oral Biology, Faculty of Dentistry, Ain Shams University, Egypt

\begin{abstract}
Background: Structural changes occur with aging, associated with fibrosis and inflammation in body tissues. Aging of oral mucosa causes alterations in oral epithelium and sub-epithelial tissues, due to reduction in certain growth factors, endogenous anti-oxidant enzymes, or both. Aim: to assess anti-aging potential of melatonin \& vitamin C on albino rats' lips.

Materials and Methods: 28 male albino rats were used, divided into: Group I: 7 rats aged 6 months (18 years in humans), Group II: 21 rats aged 24 months (72 years in humans), were equally subdivided into 3 subgroups 7 rats each as follows: Subgroup IIA: positive control for other subgroups; Subgroup IIB: received melatonin via gastric gavage (10mg/kg/day) for six consecutive weeks; Subgroup IIC: received vitamin C via gastric gavage $(2 \mathrm{mg} / \mathrm{ml} /$ day) for six consecutive weeks. At the end of the experiment, rats were sacrificed by a high dose of anesthesia. The lips were excised. Specimens were processed for histological examination, stained by H\&E, Masson's Trichrome\& Anti-VEGF, examined by light microscope.

Results: Subgroup IIA showed statistically significant increase in number of vacuolated epithelial cells, statistically significant reduction in VEGF positive cells, apparent decrease in epithelial thickness, statistically significant reduction in immature collagen fibers' percentage within connective tissue (CT). Subgroups IIB \& IIC, showed significant reduction in number of vacuolated epithelial cells and significant increase in VEGF positive cells and area percentage of immature collagen fibers in CT. However, subgroup IIB's epithelial structure showed better image and subgroup IIC's CT structure presented better image.

Conclusion: Aging showed structural changes in skin \& mucous membrane sides of rat lips, observed within both epithelium and CT. Melatonin \& vit. C exhibited efficiency in counteracting these effects. Melatonin presented superior effect on keratinocytes, vit. C showed superiority in repairing senile CT components.
\end{abstract}

Received: 13 July 2020, Accepted: 03 August 2020

Key Words: Age-related changes, lips, melatonin, vitamin C.

Corresponding Author: Rania Ahmed Awwad, PhD, Department of Oral biology, Faculty of Dentistry, Ain Shams University, Egypt, Tel.: +20 122 2390329, E-mail: rania.a.awwad@dent.asu.edu.eg - rania.a.awwad@gmail.com

ISSN: $1110-0559$, Vol. 44, No.2

\section{INTRODUCTION}

Aging, also known as time-dependent functional deterioration, has grabbed scientists' attention decades ago. Aging is characterized by a gradual reduction of physiological integrity, resulting in malfunction, reduced quality of life, and eventually death. This deterioration leads to many diseases such as, diabetes, cardiovascular disorders, neuro-degenerative diseases and various neoplasms ${ }^{[1,2]}$.

Labial tissues of both lips are composed of several layers including epidermis, sub-cutaneous tissue, Orbicularis Oris muscle fibers, and mucosa. The vermilion border (only found in humans) consists of thin keratinized stratified squamous epithelium overlying CT layer rich in blood vessels, which give the vermilion border its characteristic reddish color. Numerous minor salivary glands can be also observed in the lamina propria of the mucous membrane side of the lip. Hair follicles and sebaceous glands are found in the skin side of the $\operatorname{lip}^{[3]}$. Oral cavity lining acts as a barrier that provides protection from masticatory forces and other harmful insults. However, structural and functional alterations occur with senility, and are associated with fibrosis and inflammation in various tissues, including the oral mucosa ${ }^{[4-6]}$. CT is one of the few tissues in which extensive age-related changes occur. With age, musculo-skeletal tissues show enhanced osteoporosis, reduced ligament elasticity, loss of muscle fibers' mass, diminished cartilage resilience and accumulation of adipose tissue in abnormal locations, thus reducing tissues' ability to carry out their normal functions. Hence, senility results in diminished vascularity of body tissues, which in turn leads to in-efficient elimination of harmful end products of various cellular activities ${ }^{[7]}$. Vascular Endothelial Growth Factor (VEGF) is a 45-kDa glycoprotein which plays a major signaling role in angiogenesis. It was previously known as vascular permeability factor (VPF), and it is a signal protein produced by cells to stimulate formation of blood vessels. It is used by researchers to assess the angiogenic (and hence, the regenerative) potential of a tissue ${ }^{[8,9]}$.

Melatonin (5-Methoxy-N-Acetyltryptamine) was first discovered in 1958 and was classified as a potent antioxidant ${ }^{[10]}$. Melatonin is synthesized mainly by the pineal gland and to a lesser extent, by a variety of cells from other body tissues. Pinealocytes, are responsible for synthesis and secretion of melatonin into blood stream. An interesting finding, is that melatonin was detected in the oral cavity due 
to its release into the saliva ${ }^{[1-14]}$. Melatonin has important physiological functions that have not been properly nor sufficiently used in dentistry. Moreover, it might have clinical applications for improving oral health, and it could be used locally in managing oral lesions such as bacterial and viral lesions, and after oral surgeries ${ }^{[15]}$. Similarly, topically applied melatonin was proven to minimize the formation and to inhibit accumulation of reactive oxygen species (ROS) hence, delaying signs of skin aging ${ }^{[16]}$.

The potent antioxidant properties of vitamin C (L- ascorbic acid) and its role in collagen synthesis make it a vital molecule for skin health. Vitamin C (vit C) is a normal skin component, found in high amounts in dermis and epidermis. It is a small molecular weight antioxidant, and a crucial element for collagen synthesis ${ }^{[17-19]}$. Vit. C content of the epidermis could be greater than in the dermis. Other water-soluble antioxidants could be also detected within body tissues, such as glutathione ${ }^{[19-21]}$. Aging, however, causes declination in vit. $\mathrm{C}$ content in the $\mathrm{CT}$ of various body regions. Prolonged exposure to UV light or various pollutants could also reduce vit. C content, especially in the epidermis ${ }^{[21-23]}$. Skin vit. $\mathrm{C}$ is normally transmitted via bloodstream, and it was reported that keratinocytes have high affinity for vit. $\mathrm{C}$ transport, possibly to balance for the restricted vascularization of the epidermis $^{[24,25]}$. Oral supplementation increases vit. $\mathrm{C}$ levels in the skin. However, when plasma vit. C level is saturated, skin vit. $\mathrm{C}$ concentration does not increase ${ }^{[26,27]}$.

\section{AIM OF THE WORK}

The aim of the present work was to assess and compare the anti-aging effect of melatonin and vit $\mathrm{C}$ on the labial tissues of albino rats.

\section{Null Hypothesis}

This study design was based on the hypothesis that there is no difference between vit. $\mathrm{C}$ and melatonin regarding the attenuation of age-related changes in the labial structures of albino rats.

\section{MATERIALS AND METHODS}

\section{A) Materials}

\section{1-Animals}

Twenty-eight male albino rats were used in the present study. The animals aged 6 and 24 months and were housed in wire mesh dated cages, in the animal house of the Medical Research Centre, Faculty of Medicine, Ain Shams University, under controlled temperature and dark-light cycle. They were fed standardized diet and tap water was available ad libitum, as reviewed and approved by institution guide lines of Ain Shams University Ethical Committee. (Approval number: FDASU - REC IR 101903).

2-Melatonin, in the form of rapid release capsules (10mg) was purchased from (Puritan's Pride NY, USA).

3-Ascorbic acid (vit. C), was purchased from (Al Hadidi Pharma, Egypt) in the form of oral drops $100 \mathrm{mg} / \mathrm{ml}$.

\section{B) Methods}

\section{Experimental design}

\section{Animal grouping}

The rats were divided into 2 main groups:

Group (Gp) I: Consisted of seven rats aged 6 months (equivalent to 18 years in humans) ${ }^{[28]}$, served as negative (-ve) control.

Gp II: Consisted of twenty-one rats aged 24 months (equivalent to 72 years in humans) ${ }^{[28]}$, and were equally subdivided into 3 subgroups, seven rats each as follows:

Subgroup IIA: Animals in this subgroup served as a positive $(+v e)$ control for other subgroups.

Subgroup IIB: Animals in this subgroup received melatonin via gastric gavage at a dose of $10 \mathrm{mg} / \mathrm{kg} /$ day dissolved in $1 \mathrm{ml}$ of distilled water, for six consecutive weeks $^{[29]}$.

Subgroup IIC: Animals in this subgroup received vit. C via gastric gavage at a dose of $2 \mathrm{mg} / \mathrm{ml} /$ day for six consecutive weeks $^{[30]}$.

\section{Specimens'Preparation}

At the end of the experimental period (six weeks), rats were sacrificed by a high dose of anesthesia. The lips were excised free. Specimens were fixed in $10 \%$ buffered formaldehyde for 48 hours, and then prepared for examination by H\&E and Masson's Trichrome special stain as follows: The specimens were properly washed under running water then dehydrated by transferring them through increasing concentrations of alcohol. Then, specimens were transferred to xylene to be cleared from alcohol, infiltrated in paraffin and embedded in paraffin wax blocks' center. $4 \mu \mathrm{m}$-thick sections were put in xylene and transferred in descending concentrations of alcohol then distilled water for removal of paraffin wax. The sections were finally stained by Hematoxylin \& Eosin (H\&E), Masson's Trichrome special stain, which is a staining technique implemented for the detection of collagen and to distinguish between mature and immature collagen fibers in tissues. Immature collagen fibers will be stained blue while the mature ones will appear reddish in color. Specimens were also stained by Anti-Vascular Endothelial Growth Factor (VEGF) to evaluate angiogenic and regenerative capacity of the tissue ${ }^{[31,32]}$.

\section{Immunohistochemical staining using Anti-VEGF}

Four- $\mu$ m-thick sections were mounted on +ve charged slides and dried for 60 minutes at $65 \mathrm{C}^{\circ}$. Sections were dewaxed in Xylene and rehydrated through graded series of ethanol and rinsed in water. Endogenous peroxidase activity was blocked with $3 \%$ hydrogen peroxide for $10 \mathrm{~min}$. Heatinduced antigen recovery was done in a microwave oven in $10 \mathrm{mM}$ Tris/EGTA ( $\mathrm{pH}=9)$ by heating for $10 \mathrm{~min}$. Sections were cooled for $15 \mathrm{~min}$ at room temperature and rinsed in Tris-buffered saline (TBS) with $0.05 \%$ Tween 20 for at least $5 \mathrm{~min}$. Sections to be incubated in anti VEGF were 
also treated with $0.5 \%$ casein in TBS for 10 min to block non-specific binding sites. Tissue sections were incubated with primary antibody for $30 \mathrm{~min}$ : anti-VEGF-A, rabbit polyclonal antibody, dilution 1:250 (A-20, SC-152, Santa Cruz Biotechnology Inc., Santa Cruz, CA). Detection was made using Super Sensitive Polymer-HRP IHC Detection System. Super Enhancer link was added for $20 \mathrm{~min}$ and polymer-HRP for $30 \mathrm{~min}$ followed by visualization with DAB chromogen for $12 \mathrm{~min}$. Sections were rinsed in water, and $0.5 \%$ copper sulfate in TBS was added to increase staining quality. Sections were rinsed multiple times in TBS buffer between incubations. Finally, sections were counterstained with hematoxylin, dehydrated, and cover slipped. Positive reaction was detected as brown color. The cellular localization of this antibody is nuclear and cytoplasmic ${ }^{[33]}$.

\section{Histo-morphometric Analysis}

Image J software (Version 1.41a, NIH, USA) was used for histo-morphometric analysis, in the Precision Measurement Unit, Oral Pathology Department, Faculty of Dentistry, Ain Shams University. Images of selected H\&E-stained sections were analyzed by the software to assess the number of vacuolated epithelial cells per unit area of the epithelium, and to measure the epithelial thickness of the studied specimens. Also, this software assessed the area percentage of immunepositive cells in Anti-VEGF-stained sections. In Masson's Trichrome-stained sections, this software measured the area percentage of immature versus mature collagen fibers within the CT.

\section{Statistical analysis}

Numerical data of mean number of vacuolated epithelial cells, mean area percentage of Anti-VEGF positive cells, epithelial thickness among tested groups, and area percentage of collagen fibers were examined for normality by monitoring the distribution of data and using tests of normality. One-way ANOVA test was performed to compare between the four groups. When ANOVA test was significant, Bonferroni's post-hoc test was done for pair-wise comparisons between each two groups. The significance level was set at $P \leq 0.05$. Statistical analysis was performed using IBM ${ }^{\circledR}$ SPSS ${ }^{\circledR}$ Statistics Version 21 for Windows.

\section{RESULTS}

I) Routine Histological Examination $(H \& E$ stained sections)

\section{A) Light Microscopic Examination of Specimens of Gp I (6m)}

Examination of H\&E stained sections of mucous membrane side of this $\mathrm{Gp}$ revealed normal histological features of the surface epithelium and the underlying CT. The stratified squamous keratinized epithelium was of uniform thickness and different layers were quite obvious, and was covered by a uniform keratin layer. In the lamina propria, densely packed collagen fiber bundles were observed and apparently numerous blood vessels (Figure 1a). While the skin side of specimens from the same Gp showed almost normal keratinized stratified squamous epithelium of the epidermis. The hair follicles were apparently numerous and the CT of the dermis appeared normal (Figure 1b).

\section{B) Light microscopic examination of specimens of Gp II (24m)}

\section{Subgroup IIA (24 months; Positive Control)}

Examination of H\&E stained sections of mucous membrane side of this Gp revealed apparent thinning in the epithelium with obviously thin, disrupted, and discontinuous keratin layer. Less interdigitation was observed with the underlying dermis which appeared more fibrotic in the papillary layer compared to Gp I $(6 \mathrm{~m})$ while the deeper layers showed areas of complete degeneration and hyalinization with appearance of some inflammatory cells. Apparent decrease in the number of blood vessels was also observed with obvious thickening in their walls (Figure 1c). While, the skin side of specimens from the same Gp showed some alterations as, keratin detachment from the superficial layer was obvious in most specimens. Also, fewer number of hair follicles, sweat and sebaceous glands was apparent. Disruption of hair shafts with edematous areas around hair shafts was also observed (Figure 1d).

\section{Subgroup IIB (Melatonin)}

Examination of H\&E stained sections of mucous membrane side and skin side of this Gp showed almost similar histological features compared to Gp I except for small areas of CT alterations, such as dilation of some blood vessels. (Figures 1e,f).

\section{Subgroup IIC (Vit. C)}

Examination of H\&E stained sections of mucous membrane side and skin side of this Gp showed histological features similar to Gp I. Additionally, the CT presented numerous well-formed blood vessels in the mucous membrane side of the lip (Figure 1g). The skin side showed localized areas of keratin detachment, CT displayed numerous well-formed hair follicles (Figure 1h).

\section{II) Histochemical Examination (Masson's Trichrome stained sections)}

\section{Gp I}

Examination of Masson's Trichrome-stained sections of mucous membrane side and skin side of this Gp revealed numerous areas of predominating blue color (immature collagen) intermingled with few areas of red color (mature collagen), (Figures $2 \mathrm{a}, \mathrm{b}$ ).

\section{Subgroup IIA (Positive Control)}

Examination of Masson's Trichrome stained sections of mucous membrane side and skin side of this Gp revealed numerous areas of predominating red color and complete absence of blue color (Figures $2 \mathrm{c}, \mathrm{d}$ ). 


\section{Subgroup IIB}

Examination of sections of mucous membrane side and skin side of this $\mathrm{Gp}$ revealed predominance of blue color while few areas appeared red (Figures 2 e, f).

\section{Subgroup IIC}

Examination of sections of mucous membrane side and skin side of this Gp revealed intermingling of blue and red colors with the blue color predominating (Figures $2 \mathrm{~g}, \mathrm{~h}$ ).

\section{III) Immunohistochemical examination (Anti-VEGF stained sections)}

\section{Gp I}

Examination of anti-VEGF stained sections of this Gp revealed relatively numerous areas of brown color (positive reaction) scattered throughout the epithelium and $\mathrm{CT}$ (Figure 3a).

\section{Subgroup IIA (Positive Control)}

Examination of anti-VEGF stained sections of this Gp revealed few areas of brown coloration, scattered within the epithelium and $\mathrm{CT}$, intermingling with many areas of negative reaction (Figure $3 b$ ).

\section{Subgroup IIB}

Examination of anti-VEGF stained sections of this Gp revealed numerous areas of intense positive reaction within the epithelium and some scattered areas in the CT (Figure 3c).

\section{Subgroup IIC}

Examination of anti-VEGF stained sections of this Gp revealed numerous areas of positive reaction within the

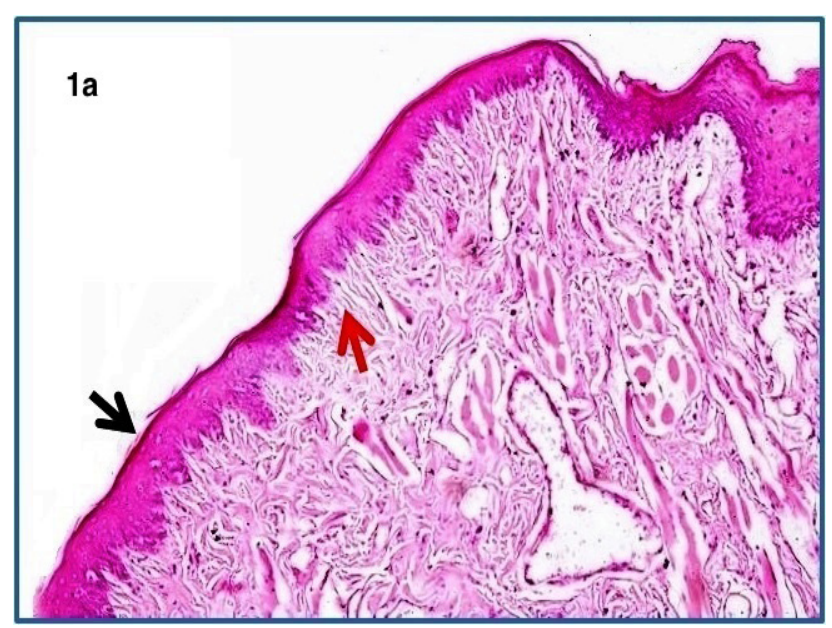

epithelium and extensively numerous areas of positive reaction within the CT and blood vessels (Figure 3d).

\section{Statistical analysis}

Data were statistically analyzed in terms of mean \pm standard deviation ( \pm SD). Comparison of numerical variables between the study groups were done using one-way analysis of variance (ANOVA) test with Post HOC multiple 2-group comparisons. $P$-values less than 0.05 was considered statistically significant. All statistical calculations were done using computer program SPSS (Statistical Package for the Social Science; SPSS 20.0, Inc., Chicago, IL, USA).

The results of the present study are demonstrated in the following tables and (Figures 4,5,6,7).

(Table 1) shows highly statistically significant difference

between groups according to their collagen content regarding mature and immature $\%$.

(Table 2) shows no statistically significant differencebetween groups according to their epithelial thickness.

(Table 3) shows highly statistically significant differencebetween groups according to their number of vacuolatedepithelial cells.

(Table 4) shows highly statistically significant differencebetween groups according to their area percentage of positive VEGF cells.

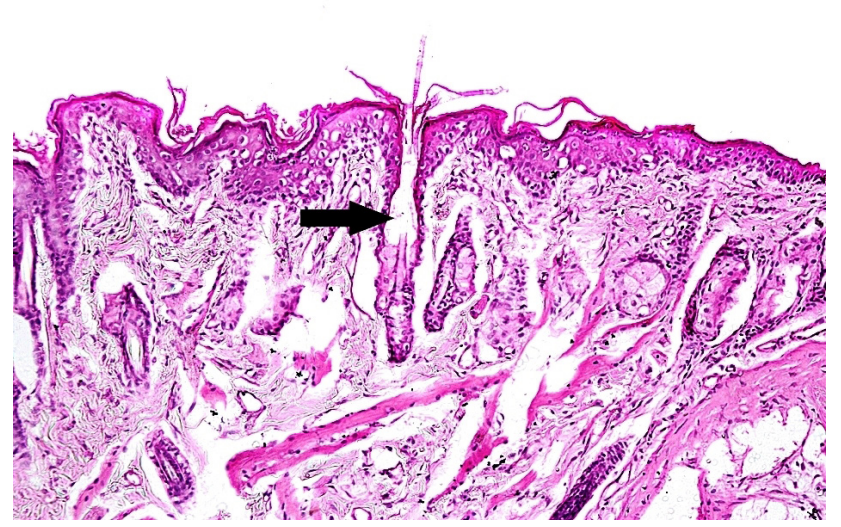



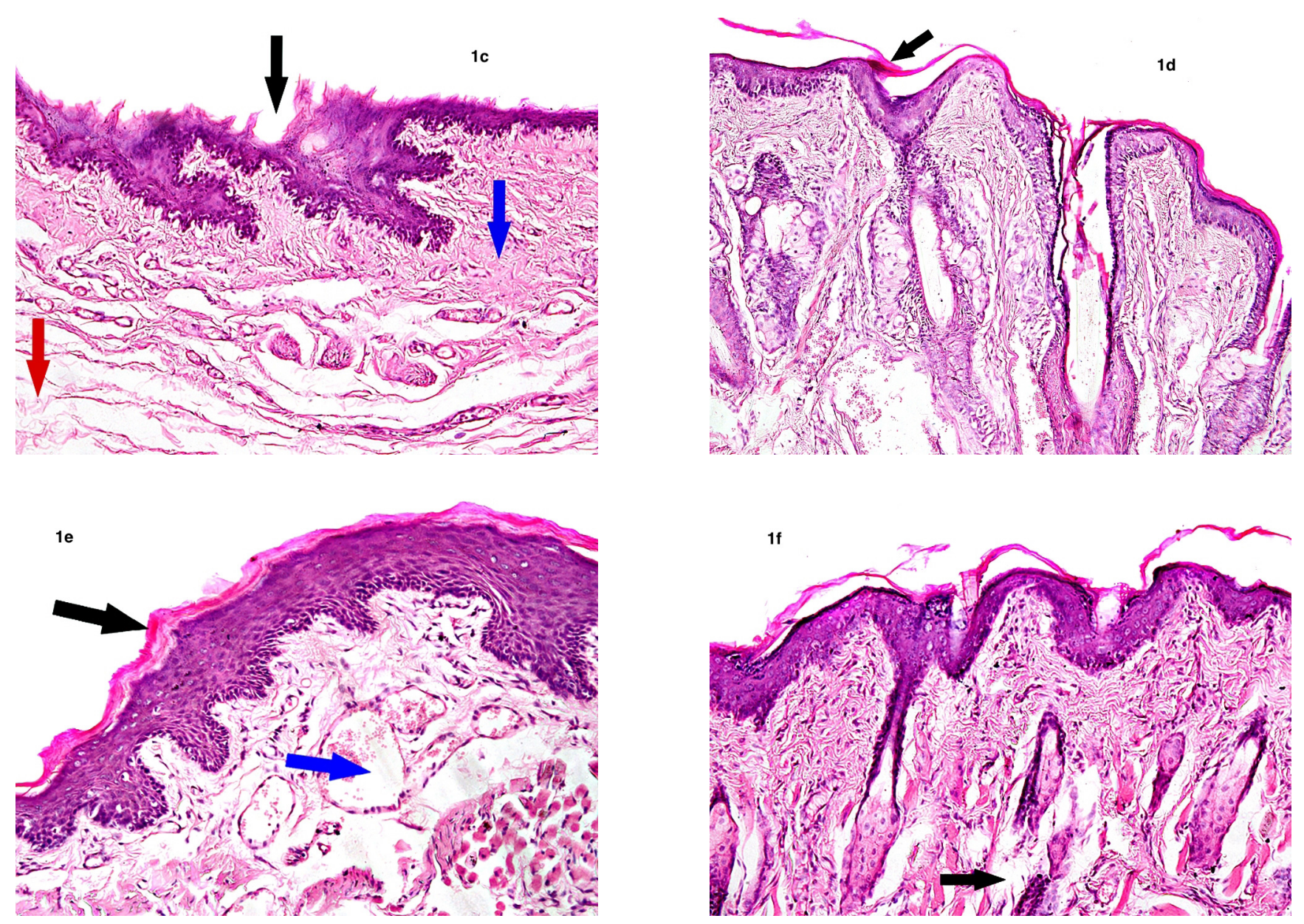

19

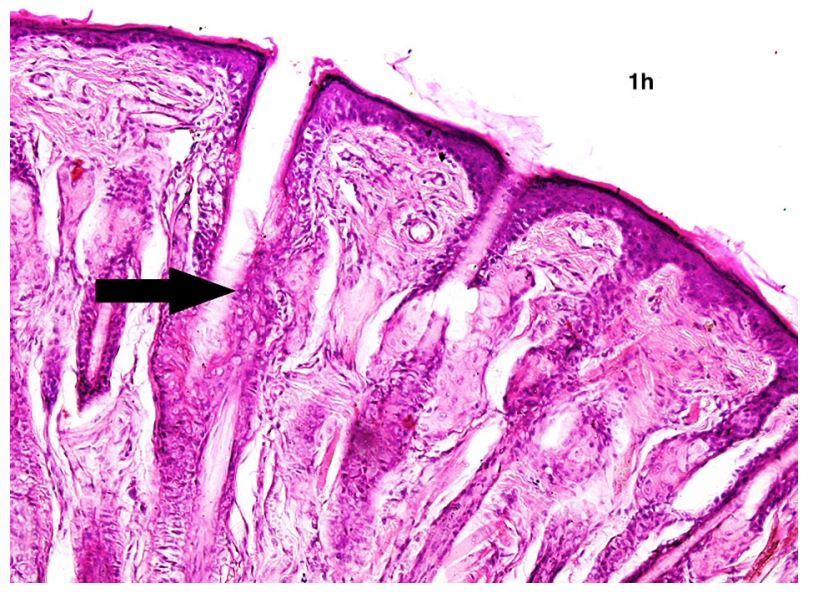

Fig. 1: Photomicrographs of mucous membrane and skin sides respectively, of lip of a rat of : group I (negative control) showing: a- Normal stratified squamous epithelium with sound keratin layer (black arrow) and lamina propria (red arrow). b- The hair follicles were apparently numerous and the CT of the dermis appeared normal; subgroup IIA (positive control) showing: c- Apparent thinning of epithelium, thin, disrupted keratin layer (black arrow), more fibrotic papillary layer (blue arrow), areas of complete degeneration and hyalinization as well as extracellular edema (red arrow) with apparent decrease in the number of blood vessels. d- Keratin detachment from the surface layer (black arrow), fewer number of hair follicles, sweat and sebaceous glands. Disruption of hair shafts, edematous areas around hair shafts; subgroup IIB (Melatonin) showing: e- Thick epithelium with sound keratin layer (black arrow), some CT changes as dilated blood vessels (blue arrow), f- Rarely detected extracellular edema and disrupted hair follicles (black arrow); subgroup IIC (vit C) showing: g- Almost normal appearance of epithelium \& CT. CT showed numerous blood vessels (black arrows). h- Skin side showed minimal keratin detachment. CT presented numerous well-formed hair follicles (black arrow). (H\&E, x400). 

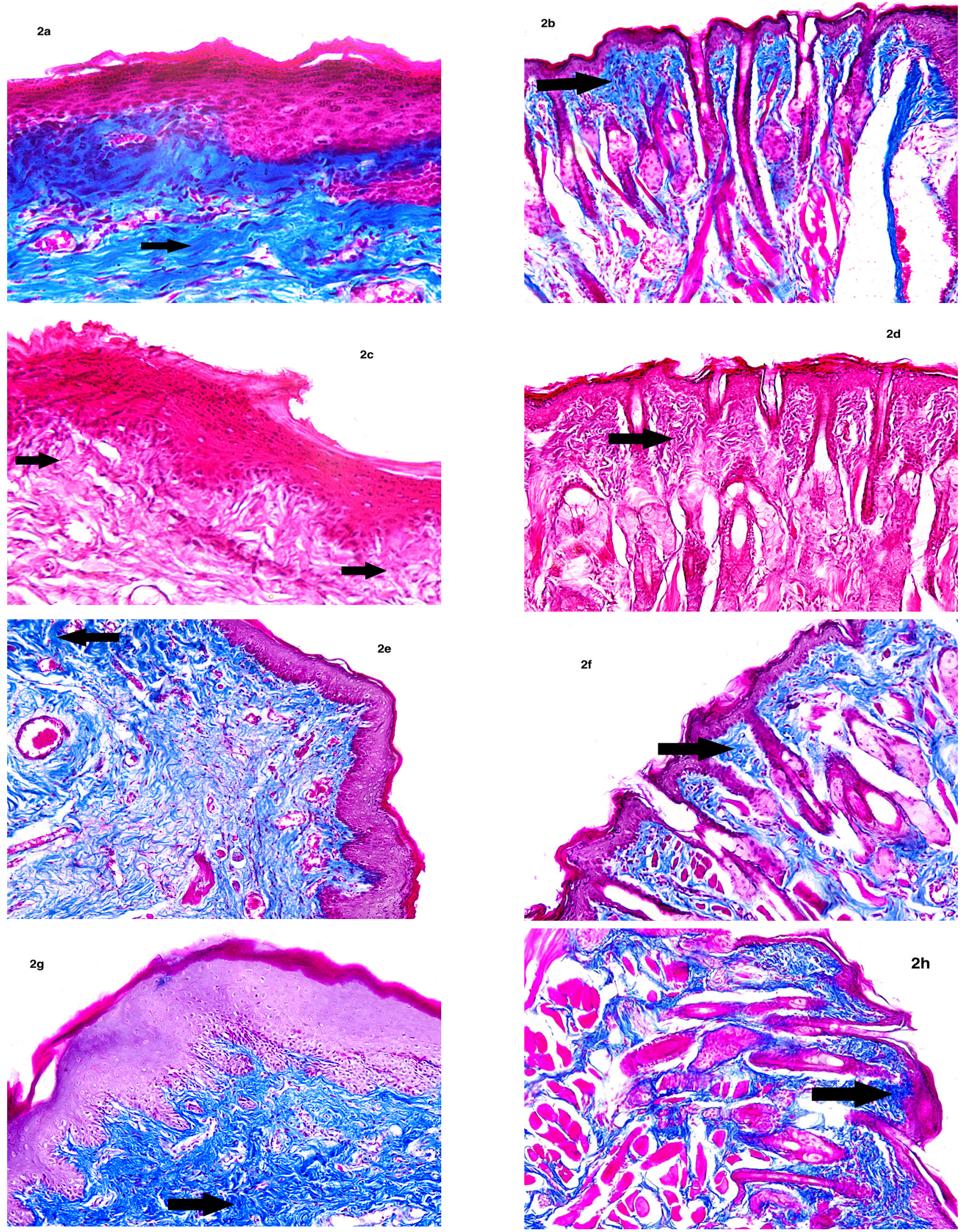

Fig. 2: Photomicrographs of mucous membrane and skin sides respectively, of lip of a rat of : group I showing in : a \& b predominating blue color in the CT (black arrows); subgroup IIA showing in c \& d : predominance of red color and complete absence of blue color in the CT (black arrows); subgroup IIB showing in e \& $\mathrm{f}$ : predominance of blue color (black arrow); subgroup IIC showing in $\mathrm{g} \& \mathrm{~h}:$ intermingling of blue and red colors with predominance of the blue color in the mucous membrane side (black arrow). (Masson's Trichrome, $\mathrm{x} 400$ ). 

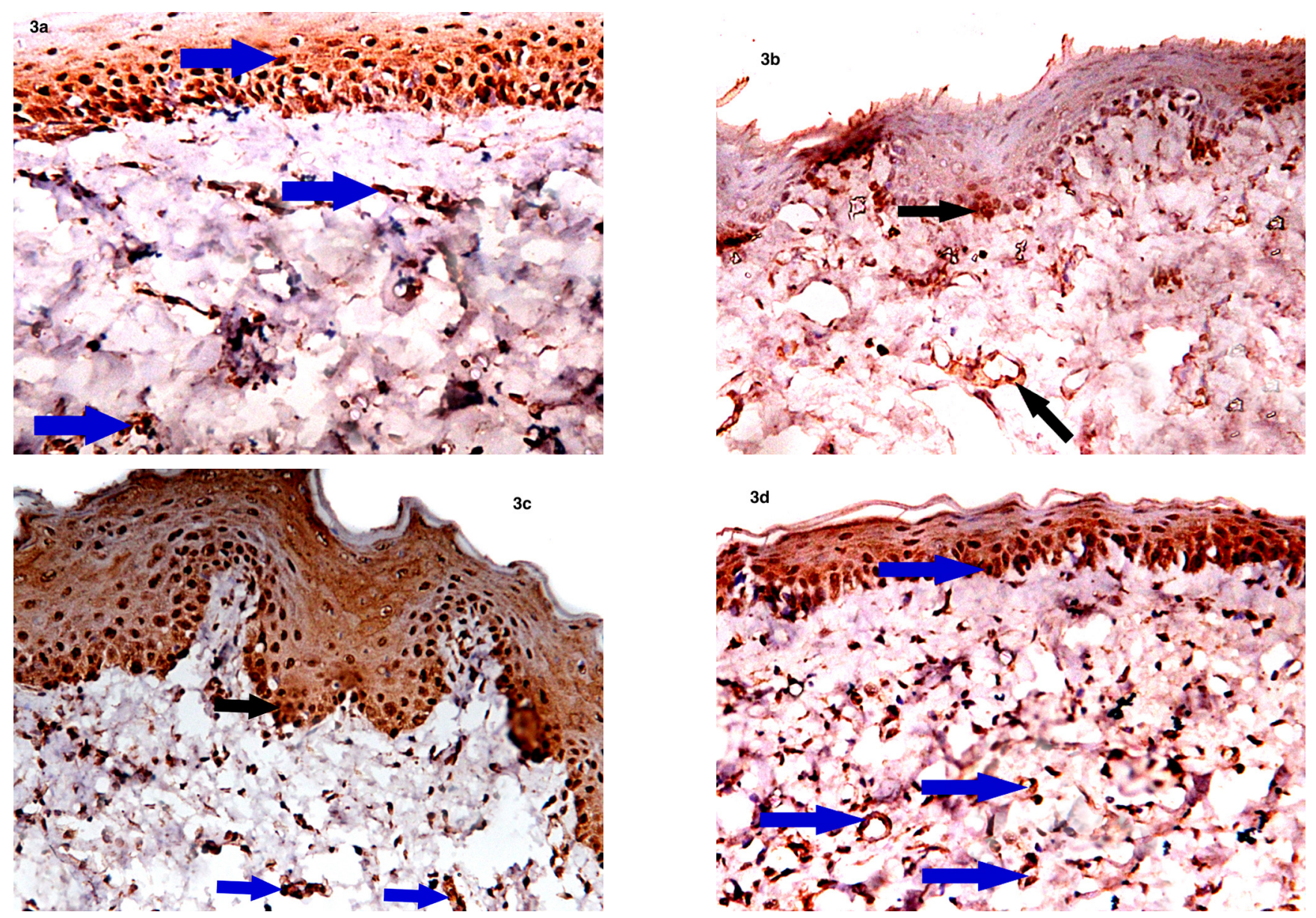

Fig. 3: Photomicrographs of mucous membrane of lip of a rat of : group I showing in a: Numerous positively stained cells (brown) scattered through the epithelium and CT(blue arrows); subgroup IIA showing in b: Few scattered positively stained cells (brown) within the epithelium and CT (black arrows); subgroup IIB showing in c: Numerous areas of intense positive reaction within the epithelium (black arrow) and some scattered areas in the CT (blue arrows); subgroup IIC showing in d: Numerous areas of positive reaction in the epithelium and relatively more numerous areas of positive reaction in the CT (blue arrows). (Anti-VEGF, x 400).

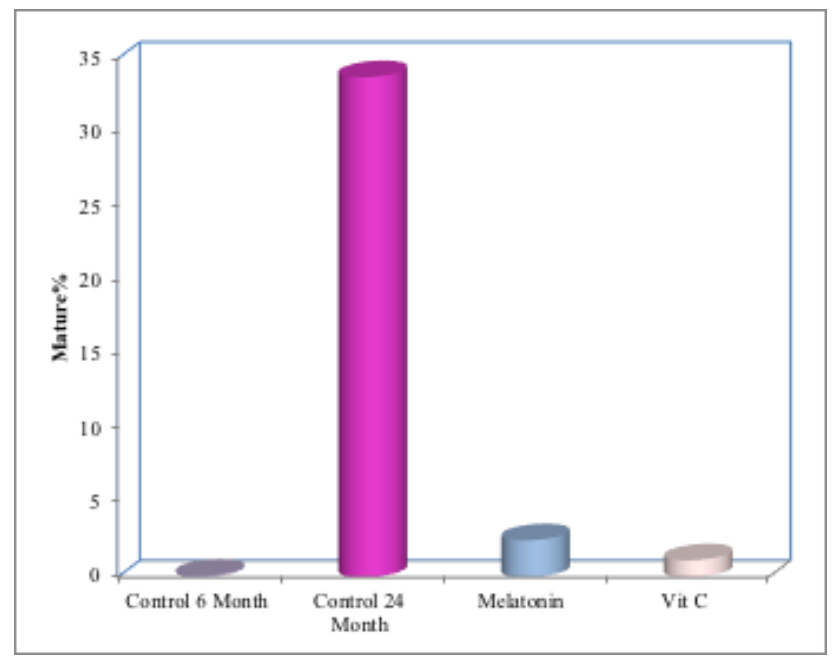

Fig. 4: Bar chart between groups according to their mature collagen $\%$.

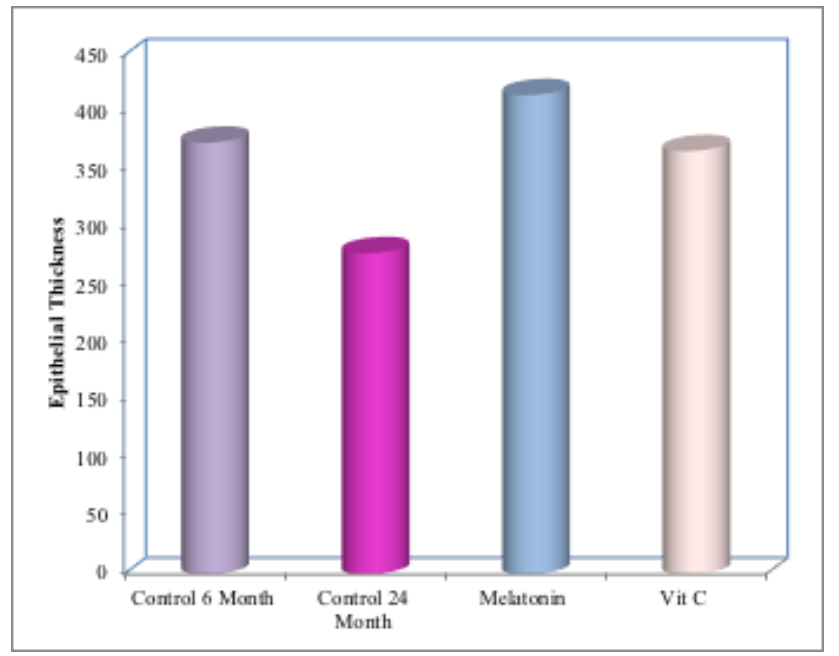

Fig. 5: Bar chart between groups according to their epithelial thickness 


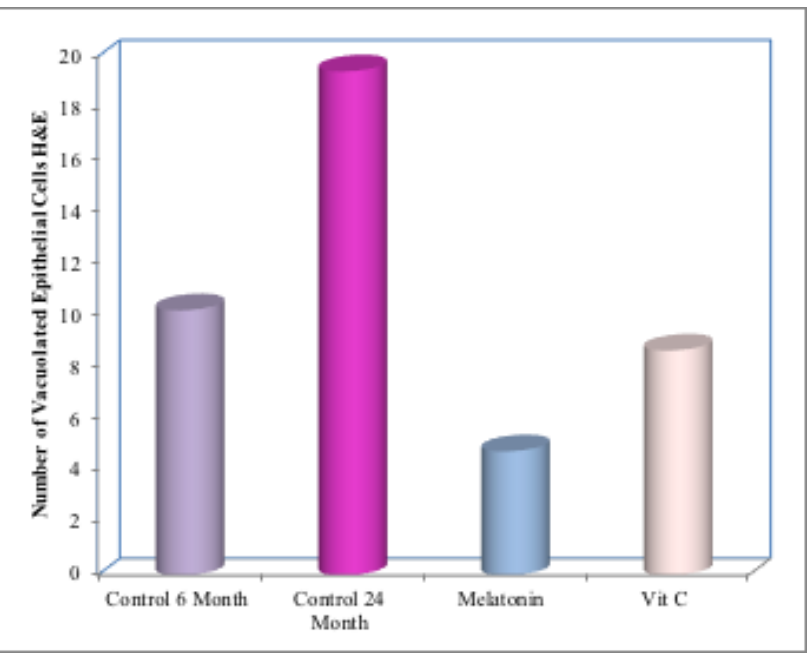

Fig. 6: Bar chart between groups according to the number of vacuolated cells in Epithelium.

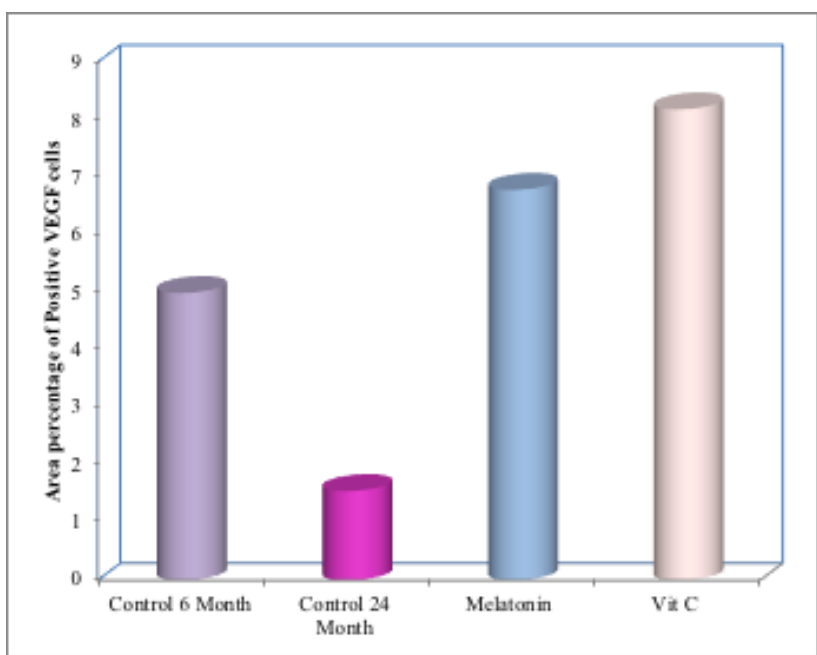

Fig. 7: Bar chart between groups according to their area percentage of positive VEGF cells

Table 1: Comparison between groups according to their mature and immature collagen $\%$.

\begin{tabular}{|c|c|c|c|c|c|c|}
\hline Collagen $\%$ & Control 6 Month $(\mathrm{n}=3)$ & Control 24 Month $(\mathrm{n}=3)$ & Melatonin $(n=3)$ & Vit $C(n=3)$ & $\mathrm{F}$ & p-value \\
\hline \multicolumn{7}{|l|}{ Mature $\%$} \\
\hline Mean \pm SD & $0.11 \pm 0.18$ & $32.98 \pm 5.57^{\mathrm{a}}$ & $2.49 \pm 3.50^{\mathrm{b}}$ & $1.14 \pm 1.08^{\mathrm{b}}$ & \multirow{2}{*}{69.99} & \multirow{2}{*}{$<0.001^{* *}$} \\
\hline Range & $0-0.29$ & $26.89-37.90$ & $0-5.98$ & $0-2.14$ & & \\
\hline \multicolumn{7}{|l|}{ Immature $\%$} \\
\hline Mean \pm SD & $28.01 \pm 6.02$ & $0.415 \pm 0.55^{\mathrm{a}}$ & $29.95 \pm 9.60^{\mathrm{b}}$ & $49.74 \pm 12.60^{\mathrm{abc}}$ & \multirow{2}{*}{17.91} & \multirow{2}{*}{$<0.001^{* *}$} \\
\hline Range & $25.90-34.98$ & $0-0.96$ & $19.87-37.95$ & $38.08-63.11$ & & \\
\hline
\end{tabular}

F- One Way Analysis of Variance; $* * p$-value $<0.001 \mathrm{HS}$; n: number of selected representative fields per group.

Post HOC test LSD: a: significant difference with control 6 months; b: significant difference with control 24months;

c: significant difference with melatonin

Table 2: Comparison between groups according to their epithelial thickness.

\begin{tabular}{|c|c|c|c|c|c|c|}
\hline Epithelial Thickness & Control 6 Month $(n=7)$ & Control 24 Month $(n=7)$ & Melatonin $(n=7)$ & Vit $C(n=7)$ & $\mathrm{F}$ & $p$-value \\
\hline Mean \pm SD & $401.01 \pm 104.62$ & $265.20 \pm 110.63$ & $453 \pm 132.61$ & $367.18 \pm 172.69$ & \multirow{2}{*}{0.598} & \multirow{2}{*}{0.396} \\
\hline Range & $200.01-821$ & $79.599-622$ & $140-634$ & $151.789-618.029$ & & \\
\hline
\end{tabular}

F- One Way Analysis of Variance; $p$-value $>0.05$ NS; n: represents number of specimens per group

Table 3: Comparison between groups according to their number of vacuolated epithelial cells.

\begin{tabular}{|c|c|c|c|c|c|c|}
\hline $\begin{array}{c}\text { Number of } \\
\text { Vacuolated Epithelial } \\
\text { Cells H\&E }\end{array}$ & Control 6 Month $(\mathrm{n}=9)$ & Control 24 Month $(\mathrm{n}=9)$ & Melatonin $(n=9)$ & Vit $C(n=9)$ & $\mathrm{F}$ & p-value \\
\hline Mean \pm SD & $10.22 \pm 5.61$ & $19.44 \pm 7.33 \mathrm{a}$ & $4.78 \pm 3.23 \mathrm{ab}$ & $8.67 \pm 4.39 \mathrm{~b}$ & \multirow{2}{*}{12.1} & \multirow{2}{*}{$<0.001^{* *}$} \\
\hline Range & $3-21$ & $12-32$ & $0-11$ & $3-14$ & & \\
\hline
\end{tabular}

F- One Way Analysis of Variance; $p$-value $>0.05 \mathrm{NS}$; n: represents number of specimens per group

Table 4: Comparison between groups according to their area percentage of positive VEGF cells.

\begin{tabular}{lcccc}
\hline $\begin{array}{c}\text { Area percentage of } \\
\text { Positive VEGF cells }\end{array}$ & Control 6 Month $(\mathrm{n}=6)$ & Control 24 Month $(\mathrm{n}=6)$ & Melatonin $(\mathrm{n}=6)$ & Vit C (n=6) \\
\hline Mean \pm SD & $4.99 \pm 0.28$ & $1.55 \pm 0.27 \mathrm{a}$ & $6.78 \pm 0.96 \mathrm{ab}$ & $8.18 \pm 0.29 \mathrm{abc}$ \\
Range & $4.62-5.34$ & $1.1-1.85$ & $5.56-7.84$ & $7.85-8.52$ \\
\hline
\end{tabular}

F- One Way Analysis of Variance; **p-value $<0.001 \mathrm{HS}$; $\mathrm{n}$ : represents number of selected representative fields per group.

Post HOC test LSD: a: significant difference with control 6 months; b: significant difference with control 24months;

c: significant difference with melatonin 


\section{DISCUSSION}

"The surest poison is time" as stated by Ralph waldo. Actually, aging is a very aggressive, biological process resulting in structural and functional deterioration of the body with age. However, this process is variable among individuals due to differences in their genes and lifestyles ${ }^{[34]}$.

Many researches showed that albino rats grow rapidly and become sexually mature at about the 6th week, but reach their social maturity 5-6 months later. After puberty, a rat's month is almost equal to three human years ${ }^{[28]}$. Accordingly, in this study we classified the animals into young and old groups (6 and 24 months) that are corresponding to 18 and 72 years old for human respectively.

The lining mucosa of the oral cavity is responsible for protection of the sensitive deeper tissues from forces of mastication and other potentially harmful insults. Alterations occurring within oral mucosa with aging, are reflected on the structure and function of senile tissues, minimizing their resistance to various insults ${ }^{[35]}$. Skin structural alterations also become apparent with senility, as many histological, biochemical and functional alterations occur within senile skin $^{[36]}$.

It is widely known that melatonin and vit. $\mathrm{C}$ were contemplated as anti-aging substances by many researchers due to their prominent antioxidant properties ${ }^{[12,24]}$. There were many age-related alterations in the oral mucosa described in literature, but few of those studies used quantitative approaches. Moreover, most of them had focused on changes of the oral epithelium only with rare referral to the underlying CT age changes ${ }^{[37-40]}$.

Our work aimed to assess the histological age changes of rat's labial tissues and comparing the effects of melatonin and vit. $\mathrm{C}$ dietary supplementation in minimizing these changes.

During examination of H\&E-stained sections of mucous membrane and skin sides of the subgroup IIA (positive control), we noticed an apparent epithelial thinning with disruption and discontinuity of the keratin layer, together with significant increase in the mean number of vacuolated epithelial cells. Apparently, fewer epithelial ridges were also noticed. This was in agreement with (Abu Eid et al., 2012 ${ }^{[41]}$ who observed the reduced thickness but found no change in the epithelial-CT interface with advanced age. However, other studies confirmed the less conspicuous epithelial ridges in aged $\operatorname{skin}^{[42,43]}$. Abu Eid et al. stated that the epithelial cells became flatter with age, and attributed this to changes in cellular maturation as previously reported by Dhawan and Toto $(1965)^{[44]}$. The flattening of the cells could explain the apparent reduction in epithelial thickness found in our study. Reduced corrugations of the epithelial-CT interface has been correlated with diminution in basal cells' population, (which determines the shape of the epithelial-CT interface), with senility as stated by Burns et al., 2004 ${ }^{[43,45]}$. Keratin detachment from the superficial layer in our senile untreated specimens was matching to the findings of (Manimegalai et al., 2015 $)^{[46]}$. They attributed this to many factors; as diminution of epithelial thickness with age, leading to reduction in humidity of stratum corneum producing dehydration and roughness of the skin, which is a common skin problem met in senility. Other factor could be ROS, which accumulates with age, and affects cellular functions interfering with protein synthesis, mainly keratin. Moreover, ROS accumulation resulted in enhanced apoptosis which was reflected as significantly increased vacuolated epithelial cells $^{[47,48]}$.

The CT of this Gp presented more fibrotic papillary layer in aged specimens compared to Gp I $(6 \mathrm{~m})$ while the deeper layers showed areas of complete degeneration and hyalinization together with extracellular edema. These observations were in agreement with (Geith et al., 1991) findings ${ }^{[49]}$. We attributed the degenerated areas in deeper CT layers to Matrix Metalloproteinases' (MMPs) activation as a consequence to ROS accumulation within senile tissues, resulting in massive destruction of collagen fibers as well as reduction of fibroblasts' population through enhancing apoptosis. Thus, resulting in clinically apparent alterations in senile skin, as they are responsible for the synthesis and maintenance of extra cellular matrix. Also, Raine NJ et al., 2003 ${ }^{[50]}$ reported that, collagen percentage in skin decreases with an average annual rate of $2 \%$. These previous explanations almost clarified our statistical results regarding the predominance of mature (aged) collagen in 24 months animals and the predominance of immature collagen in the younger $\mathrm{Gp}$ as demonstrated by our Masson's Trichrome stained sections.

In the current study, we observed inflammatory cells' infiltration in the CT of the same Gp. Singh et al., 2008 and Deleidi et al., 2015 also had reported that almost all body tissues including the liver, adipose tissue, brain, kidney, muscle, and heart displayed increased macrophage infiltration with senility ${ }^{[51,52]}$. Chronic inflammation, which usually occurs slowly, results in macrophage and lymphocyte accumulation. It is well established that this chronic inflammation is associated with alterations in the apoptotic signaling pathways. The un-regulated immune response is one of the key changes occurring during senility, leading to a systemic chronic inflammatory condition ${ }^{[3,54]}$.

In the current study, there was a marked reduction in blood vessels in aged rats' CT in both oral mucosa and skin sides of the same Gp, which was confirmed statistically through significant reduction in VEGF-positive cells. This came in agreement with Gunin et al., 2015 ${ }^{[55]}$ as they showed that numbers of blood vessels were gradually reduced by age. This could be due to toxic cytokines produced in chronic inflammation which probably induce death of some existing endothelial cells and impair the regeneration ability of the others $^{[56,57]}$.

Also, an obvious depletion in skin appendages was noticed in senile rats of the same Gp (subgroup IIA), matching what was stated by Zouboulis and Boschnakow, $2001^{[58]}$. 
In the current work we observed that both vit $\mathrm{C}$ and melatonin showed enhancement of skin and labial mucosal architecture in senile specimens. However, melatonin showed superior results than vit. $\mathrm{C}$ in the epithelial component. On the other hand, vit. C overcame the effect of melatonin on collagen repair and vasculo-neogenesis. These were confirmed histologically, immunohistochemically, and statistically. The predominance of blue color in Masson's Trichrome-stained specimens reflecting new collagen build up, VEGF increased immunopositivity denoted vasculoneogenesis. This marked improvement in both epithelial and CT image could be attributed mainly to the anti-oxidant role of vit. $\mathrm{C}$ and melatonin against ROS. This was manifested in this study by significant reduction in the mean number of vacuolated epithelial cells, apparent increase in epithelial thickness, significant increase in immature collagen and VEGF-positive cells in the $\mathrm{CT}^{[13,17]}$.

In this research, we noticed an apparent reduction in the inflammatory cells' infiltration in treated groups: (subgroup IIB \& IIC). The well-established anti-oxidant role of melatonin and vit. $\mathrm{C}$ might be responsible for this. Melatonin's anti-inflammatory action is also well reported, and it is known to inhibit the pro-inflammatory enzyme cyclooxygenase-2 (COX-2). It also binds to the active sites of COX-1 and COX-2 thus acting as a natural inhibitor for these enzymes and hence, a natural suppressor of inflammation. Moreover, melatonin was discovered to be a free radical scavenger and its metabolites, unlike other antioxidants, do not induce pro-oxidant reactions. Melatonin acts as a potent antioxidant also, indirectly through enhancing activity and gene expression of inherent body antioxidant enzymes. That could explain our finding of significantly reduced mean number of vacuolated epithelial cells in treated Gps, in which melatonin $\mathrm{Gp}$ showed a better result ${ }^{[13,59-67]}$.

Alterations in the structure and function of the vascular endothelium leads to endothelial dysfunction (ED). Interestingly, vit. $\mathrm{C}$ supplementation was found to reduce ED in patients with cardiac or vascular problems. Vit. C also limited ED that was experimentally induced. Enhanced endothelial function was achieved with daily intake of vit. C doses exceeding $500 \mathrm{mg}^{[68,69]}$, which matched our findings that we observed significantly increased expression of VEGF antibody in vit. $\mathrm{C}$ treated group. Moreover, it has been also reported that reduction in ROS concentration within the tissue, promoted angiogenesis and mesenchymal stem cells proliferation ${ }^{[70]}$. Meanwhile, the percentage of newly formed (immature collagen) was higher upon vit. $\mathrm{C}$ administration in the present work, which seemed logic as it is known that ascorbic acid is essential for fibroblast maturation and synthesis of collagen fiber ${ }^{\mathrm{s}[71]}$.

\section{CONCLUSIONS}

- Aging showed detrimental structural changes in skin side and mucous membrane sides of rat lips.

- These effects could be clearly observed in both epithelium and CT components.
- Melatonin and vit. C exhibited efficiency in counteracting these aging effects. However, melatonin overcame vit. C effect on the keratinocytes while vit. $\mathrm{C}$ showed superiority in repairing senile CT components. Hence, the null hypothesis was discarded.

\section{CONFLICT OF INTERESTS}

There are No Conflicts of Interest.

\section{REFERENCES}

1. Lopez C, Blasco M, Partridge L, Serrano M and Kroener GThe Hallmarks of Aging, Review. Cell, 2013 Jun 6;153(6):1194-217.

2. SN Austad. Why women live longer than men: sex differences in longevity- Gender medicine, 2006: vol 3 (2):79-92.

3. Rohrich RJ, Pessa JE. The anatomy and clinical implications of perioral submuscular fat. Plast Reconstr Surgery 2009; 124(1):266-71

4. Yang G, Wright C, Hinson M, Fernando A, Sengupta $\mathrm{S}$, Biswas $\mathrm{C}$ et al. Oxidative stress and inflammation modulate Rev-erb alpha signaling in the neonatal lung and affect circadian rhythmicity. Antioxid Redox Signal, 21 (2014), pp. 17-32

5. Selman C, Sinclair A, Pedroni S, Irvine E, Alison $\mathrm{M}$, and Withers D. Evidence that hematopoietic stem cell function is preserved during aging in longlived S6K1 mutant mice. Oncotarget. 2016 May 24; 7(21): 29937-29943.

6. Cruchly A, Williams D, Farthing P, Speight P and Lesch A. Langerhans cell density in normal human oral mucosa and skin: relationship to age, smoking and alcohol consumption. Journal of Oral Path \& Medicine Volume23, Issue2. Pages 55-59.

7. Freemont AJ, Hoyland JA (2007) Morphology, mechanisms and pathology of musculoskeletal ageing. Journal of Pathology; 211: 2, 252-259.

8. Masabumi S. A Crucial Target for Anti- and ProAngiogenic Therapies. Genes Cancer. 2011 Dec; 2(12): 1097-1105.

9. Senger, DR; Galli, SJ; Dvorak, AM; Perruzzi, CA; Harvey, VS; Dvorak, HF (25 February 1983). "Tumor cells secrete a vascular permeability factor that promotes accumulation of ascites fluid". Science. 219 (4587): 9835.

10. A. B. Lerner, J. D. Case, Y. Takahashi, T. H. Lee, and W. Mori. "Isolation of melatonin, the pineal gland factor that lightens melanocytes," Journal of the American Chemical Society, vol.. 80, no. 10, article 2587, 1958.

11. R. J. Reiter, J. R. Calvo, M. Karbownik, W. Qi, and D. X.Tan, "Melatonin and its relation to the immune system and inflammation," Annals of the New York Academy of Sciences, vol. 917, pp. 376-386, 2000. 
12. Carrillo-Vico, J. M. Guerrero, P. J. Lardone, and R. J. Reiter,"A review of the multiple actions of melatonin on the immune system," Endocrine, vol. 27, no. 2, pp. 189-200, 2005.

13. D. X. Tan, L. C. Manchester, M. P. Terron, L. J. Flores, and R. J. Reiter, "One molecule, many derivatives: a never-ending interaction of melatonin with reactive oxygen and nitrogen species?" Journal of Pineal Research, vol. 42, no. 1, pp. 28-42, 2007.

14. G. G'omez-Moreno, J.Guardia, M. J. Ferrera, A. Cutando, and R. J. Reiter "Melatonin in diseases of the oral cavity," Oral Diseases, vol. 16, no. 3, pp. 242-247, 2010.

15. Murat 'Inanc, Cengiz, Seda Cengiz, and Hom- LayWang. Melatonin and Oral Cavity. International Journal of Dentistry, Jun 2012, Article ID 491872, 9 pages ,Review Article.

16. Day C, Burgess $\mathrm{C}$ and Kircik L. Assessing the Potential Role for Topical Melatonin in an Antiaging Skin Regimen. Journal of Drugs in Dermatology: JDD, 01 Sep 2018, 17(9):966-969

17. Shindo Y, Witt E, Han D, Epstein W, Packer L. Enzymic and non-enzymic antioxidants in epidermis and dermis of human skin. J Invest Dermatol 1994;102:122-124

18. Juliet M, Anitra C, and Margreet C. The Roles of Vitamin C in skin health. Nutrients. 2017 Aug 9(8): 866.

19. Rhie G, Shin MH, Seo JY, et al. Aging- and photoagingdependent changes of enzymic and nonenzymic antioxidants in the epidermis and dermis of human skin in vivo. J Invest Dermatol 2001;117:1212-1217.

20. Lopez-Torres M, Shindo Y, Packer L. Effect of age on antioxidants and molecular markers of oxidative damage in murine epidermis and dermis. J Invest Dermatol 1994;102:476-480

21. Shindo Y, Witt E, Packer L. Antioxidant defense mechanisms in murine epidermis and dermis and their responses to ultraviolet light. J Invest Dermatol $1993 ; 100: 260-265$.

22. Thiele JJ, Traber MG, Tsang K, Cross CE, Packer L. In vivo exposure to ozone depletes vitamins $\mathrm{C}$ and $\mathrm{E}$ and induces lipid peroxidation in epidermal layers of murine skin. Free Radic Biol Med 1997; 23:385-391

23. Podda M, Traber MG, Weber C, Yan LJ, Packer L. UV-irradiation depletes antioxidants and causes oxidative damage in a model of human skin. Free Radic Biol Med 1998; 24:55-65

24. Steiling H, Longet K, Moodycliffe A, et al. Sodiumdependent vitamin $\mathrm{C}$ transporter isoforms in skin: Distribution, kinetics, and effect of UVB-induced oxidative stress. Free Radic Biol Med 2007;43:752-762.
25. Kang JS, Kim HN, Jung da J, et al. Regulation of UVB-induced IL-8 and MCP-1 production in skin keratinocytes by increasing vitamin $\mathrm{C}$ uptake via the redistribution of SVCT-1 from the cytosol to the membrane. J Invest Dermatol 2007;127:698-706.

26. McArdle F, Rhodes LE, Parslew R, Jack CI, Friedmann PS, Jackson MJ. UVR-induced oxidative stress in human skin in vivo: effects of oral vitamin $\mathrm{C}$ supplementation. Free Radic Biol Med 2002;33:1355-1362.

27. Fuchs J, Kern H. Modulation of UV-light-induced skin inflammation by D-alpha-tocopherol and L-ascorbic acid: a clinical study using solar simulated radiation. Free Radic Biol Med 1998;25:1006-1012.

28. Sengupta P. The Laboratory Rat: Relating Its Age with Human's. Int J Prev Med. 2013 June; 4(6): 624-630. PMID: 239300179.

29. Guo X, Li Y., ZhaoY, Zhai Y, and Zhang L. Anti aging effects of melatonin on the myocardial mitochondria of rats and associated mechanisms. Mol Med Rep.; 15 (1):403-410, Jan., 2017.

30. Segawa T, Miyakoshi N, Kasukawa Y, Aonuma H, Tsuchie $\mathrm{H}$ and Shimada Y. Combined treatment with minodronate and vitamin $\mathrm{C}$ increases bone mineral density and strength in vitamin $\mathrm{C}$-deficient rats. Osteoporos Sarcopenia.; 2(1): 30-37, March, 2016.

31. Bindhu P, Krishnapillai R, Thomas P and Jayanthi P. Facts in Artifacts. Journal of Oral \& Maxillofacial Pathology. 2013, vol 17, issue 3, pg 397-401.

32. Bancroft J and Gamble M. Theory and Practice of Histological Techniques. $6^{\text {th }}$ edition, 2008. Pages 146-150.

33. Maae E, Nilsen M, Steffensen K, Jackobsen E, Jackobsen A and Flemming B. Estimation of Immunohistochemical Expression of VEGF in Ductal Carcinomas of the Breast. J Histochem Cytochem. 2011 Aug; 59(8): 750-760.

34. OpenStax, Anatomy \& Physiology. OpenStax CNX. Feb 26, 2016 http://cnx.org/contents/14fb4ad7-39a14eee-ab6e-3ef2482e3e22@8.24

35. César Rivera1, María Jesús Arenas-Márquez. Gerodontology: effects of ageing on the oral mucosa Rev. Clin. Periodoncia Implantol. Rehabil. Oral Vol. 10(1); 09, 2017.

36. Farage MA, Miller KW, Elsner $\mathrm{P}$, et al. Intrinsic and extrinsic factors in skin ageing: a review. Int Cosm Sci J, 2008; 30: 87-95.

37. Barakat NJ, Toto PD, Choukas NC. Aging and cell renewal of oral epithelium. J Periodontol. 1969;40(10):599-602.

38. Karring T, Loe H. The effect of age on mitotic activity in rat oral epithelium. J Periodontal Res. 1973;8(3):164 170. doi: 10.1111/j.1600-0765.1973.tb01754.x. 
39. Hill MW, Karthigasan J, Berg J, Squier CA. Influence of age on the response of oral mucosa to injury. In: Squier CA, Hill MW, editors. The effect of aging in oral mucosa and skin. Boca Raton: CRC Press; 1994. pp. 129-142.

40. Engeland CG, Bosch JA, Cacioppo JT, Marucha PT. Mucosal wound healing: the roles of age and sex. Arch Surg. 2006;141(12):1193-1197. doi: 10.1001/archsurg.141.12.1193.

41. Abu Eid R, Sawair F, Landini G and Saku T. Age and the architecture of oral mucosa .AGE (2012) 34:651-658

42. Montagna W, Carlisle K (1990) Structural changes in ageing skin. Br J Dermatol 122(Suppl 35):61-70

43. Burns T, Breathnack S, Cox N (2004) Rook's textbook of dermatology, 7th edn. Blackwell Publishing, Oxford

44. Dhawan AS, Toto PD (1965) Renewal of cell population in palate and tongue epithelia of mice. J Dent Res 44(5):989- 995

45. Whitmore SE. Skin aging and study design. Arch Dermatol J, 1997; 11: 1460-1462.

46. Manimegalai S, Sundaram J, Venkatachalam N.Age Changes In Human Skin From 3 Years To 75 Years Of Age. International Journal of Anatomy and Research, Int J Anat Res 2015, Vol 3(4):1578-84. ISSN 2321- 4287

47. Velazquez EF, Murphy GF, Elder DE, Elenitsas R, Johnson BL, Xu X. Lever's Histopathology of the Skin. Histology of the skin. 10th Ed. Philadelphia: Lippincott Williams \& Wilkins, pp. 56-61, 2009.

48. Lavker RM, Zheng P, Dong GAged skin: A study of Light, Transmission Electron and Scanning Electron Microscopy. J Invest Dermatol, 1987;88:44s-51s.

49. Gheith EZ, Cousha FS, Abou- Rabia NM, El-Samahy $\mathrm{MH}$. Age related ultrastrurtural changes in human skin. Sci. Med. J. Cai. Med. Synd, 1991;3(4):199- 204.

50. Raine-Fenning NJ, Brincat MP, Muscat-Baron Y. Skin aging and menopause. Implications for treatment. Am Clin Dermatol J, 2003; 4: 371-378.

51. Singh P, Coskun ZZ, Goode C, Dean A, ThompsonSnipes L, Darlington G (2008). Lymphoid neogenesis and immune infiltration in aged liver. Hepatology, 47: 1680-1690.

52. Deleidi M, Jaggle M, Rubino G (2015). Immune aging, dysmetabolism, and inflammation in neurological diseases. Front Neurosci, 9: 172.

53. Chen M, Xu H (2015). Parainflammation, chronic inflammation, and age-related macular degeneration. J Leukoc Biol, 98:713-725.

54. Chung HY, Sung B, Jung KJ, Zou Y, Yu BP (2006). The molecular inflammatory process in aging. Antioxid Redox Signal, 8: 572-581.

55. Gunin A, Petrov V, Vasilieva O, and Golubtsova N. Agerelated Changes of Blood Vessels in Human Dermis. Advances in Gerontology. Vol 5, Pages 65-71, 2015.
56. Chung, J.H. and Eun, H.C., Angiogenesis in skin aging and photoaging, J. Dermatol., 2007, vol. 34, pp. 593-600

57. Seo, J.E., Kim, S., Shin, M.H., et al., Ultraviolet irradiation induces thrombospondin-1 which attenuates type I procollagen down regulation in human dermal fibroblasts, J. Dermatol. Sci., 2010, vol. 59, pp. 16-24.

58. Zouboulis, C.C., Boschnakow, A., 2001. Chronological ageing and photoageing of the human sebaceous gland. Clin Exp Dermatol 26, 600-7.

59. Reiter RJ, Calvo JR, Karbownik M, Qi W, Tan DX. Melatonin and its relation to the immune system and inflammation. Annals of the New York Academy of Sciences. 2000;917:376-386

60. Carrillo-Vico A, Guerrero JM, Lardone PJ, Reiter RJ. A review of the multiple actions of melatonin on the immune system. Endocrine. 2005;27(2):189-200.

61. Gómez-Moreno G, Guardia J, Ferrera MJ, Cutando A, Reiter RJ. Melatonin in diseases of the oral cavity. Oral Diseases. 2010;16(3):242-247.

62. Cutando A, Arana C, Gómez-Moreno G, et al. Local application of melatonin into alveolar sockets of beagle dogs reduces tooth removal-induced oxidative stress. Journal of Periodontology. 2007;78(3):576-583.

63. de la Rocha N, Rotelli A, Aguilar CF, Pelzer L. Structural basis of the anti-inflammatory activity of melatonin. Arzneimittel-Forschung. 2007;57(12):782-786.

64. Cutando A, Aneiros-Fernández J, López-Valverde A, Arias-Santiago S, Aneiros-Cachaza J, Reiter RJ. A new perspective in oral health: potential importance and actions of melatonin receptors MT1, MT2, MT3, and RZR/ROR in the oral cavity. Archives of Oral Bio.

65. Reiter RJ, Manchester LC, Tan DX. Neurotoxins: free radical mechanisms and melatonin protection. Current Neuropharmacology. 2010;8(3):194-210.

66. Fischer TW, Zbytek B, Sayre RM, Apostolov EO, Basnakian AG, Sweatman TW, et al. Melatonin increases survival of HaCaT keratinocytes by suppressing UVinduced apoptosis. J Pineal Res. 2006;40:18-26. doi: 10.1111/j.1600-079X.2005.00273.x.

67. Levine M, Padayatty SJ. Vitamin C. In: Ross AC, Caballero B, Cousins RJ, Tucker KL, Ziegler TR, eds. Modern Nutrition in Health and Disease, 11th ed. Baltimore, MD: Lippincott Williams \& Wilkins; 2014:416-426.

68. Matsuzawa Y, Kwon TG, Lennon RJ, Lerman LO, Lerman A. Prognostic value of flow-mediated vasodilation in brachial artery and fingertip artery for cardiovascular events: a systematic review and meta-analysis. J Am Heart Assoc. 2015;4(11). 
69. Chan EC, Jiang F, Peshvariya HM, Dusting GJ,. Regulation of cell proliferation by NADPH oxidase-mediated signaling: Potential roles in tissue repair, regenerative medicine and engineering. Pharmacol Ther. 2009;122(2):97-108.

70. Ashor AW, Lara J, Mathers JC, Siervo M. Effect of vitamin $\mathrm{C}$ on endothelial function in health and disease: a systematic review and meta-analysis of randomised controlled trials. Atherosclerosis. 2014;235(1):9-20

71. Nicholas N, Zachary S, Dephillipo et al., Efficacy of vitamin $\mathrm{C}$ supplementation on collagen synthesis and oxidative stress after musculoskeletal injuries : A systematic review. Orthopedic Journal of sports Medicine. 2018 
الملخص العربى

\title{
دراسة مقارنة لتأثير الميلاتونين مقابل فيتامين سي على الأنسجة الشفوية للفئران الإيضاء المسنة
}

\author{
رانية أحمد محمود عواد، مروة محمد عبد الحميد، دينا محمد عبد الخالق قشقوش
}

قسم بيولوجيا الفم بكلية طب الفم والأسنان ، جامعة عين شمس

تحدث مع الثيخوخة تغير ات بنيوية تكون مصحوبة بالتليف والإلتهابات في أنسجة الجسم. إن شيخوخة أنسجة الفم تتسبب في تغير ات في النسيج الظهاري للفم والأنسجة تحت الظهارية نتيجة لنقص في بعض عو امل النس النمو أو الإنزيمات الباطنية المضادة للأكسدة أو كلاهما معا. هدف البحث: هو تقييم قدرة الميلاتونين وفيتامين C المضادة للثيخوخة على أنسجة الثفة للفئر ان المسنة.

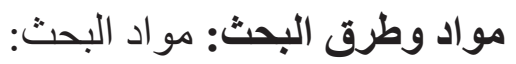

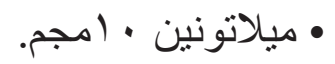

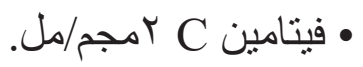
الحيو انات:

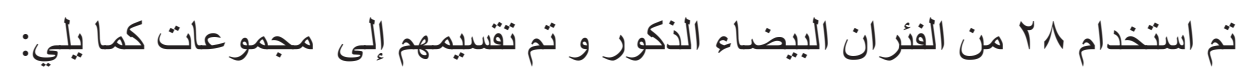

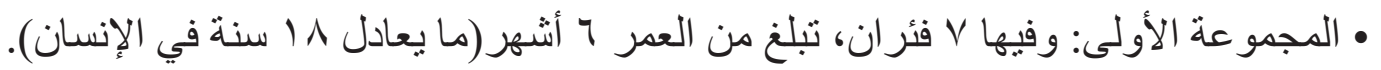

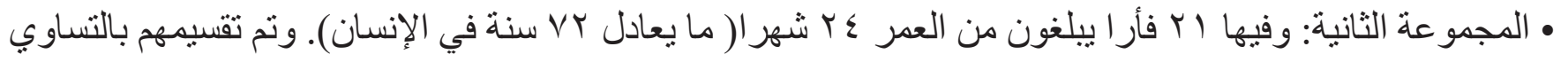
إلى س مجمو عات كما يلي:

• المجمو عة الضابطة الموجبة: وفيها V فئر ان استخدمت كمجمو عة ضابطة لباقي المجمو عات الفر عية.

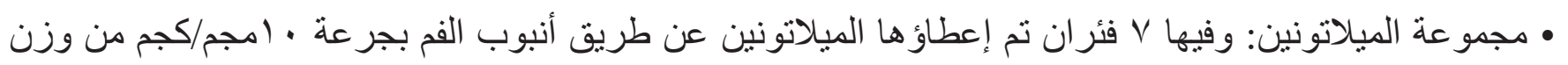
الجسم يو ميا ولمدة 7 أسابيع متتالية. • مجمو عة فيتامين C: وفيها V فئران تم إعطاؤها هيتامين C عن طريق أنبوب الفم بجرعة كمجم/مل يوميا ولمدة 7 أسابيع منتالية. في نهاية التجربة تم التضحية بالفئر ان بجر عة زائدة من المخدر ، ثم استثُصال الثنفة. بعد ذلك تم تحضير العينات للفحص المجهري بعد صبغها بالصبغات التالية: • صبغة هيماتوكسيلين وإيوسين: للفحص المجهري الروتيني. • صبغة ماسونز تر ايكروم: وهي صبغة هاصنة للكثف عن عن الكو لاجين في الانسجة.

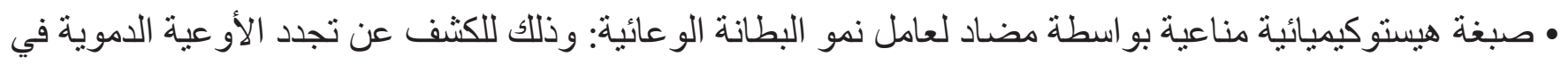

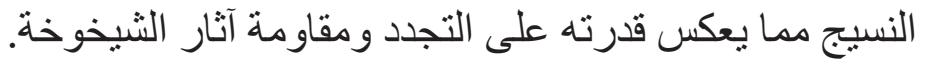
نتائج البحث: • أظهرت المجمو عة الضابطة الموجبةزيادة هامة إحصائيا في الخلايا الظهارية الجوفاء في النسيج الظهاري وفي نسبة 
ألياف الكو لاجين القديمة في النسيج الضام، ونقص هام إحصائيا في الخلايا موجبة التفاعل مع مضاد لعامل نمو البطانة الو عائية، و أيضا نقص ظاهري في سمك طبقة النسيج الظهاري.

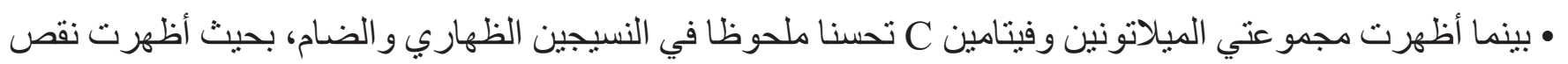

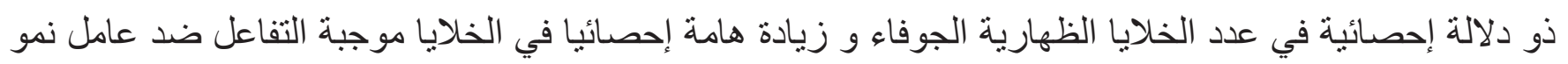
البطانة الو عائية وفي نسبة ألياف الكو لاجين الجديدة في النسيج الضام.

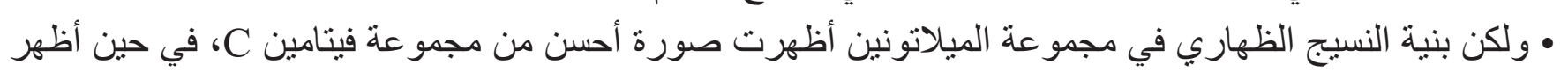
النسيج الضام صورة أحسن في مجمو عة فيتامين C من مجمو عة الميلاتونين. خلاصة البحث: ان • نتج عن الثيخوخة تغيرات بنيوية في الجلد والغشاء المخاطي المبطن لثفة الفأر، لوحظت في كل من النسيجين الظهاري و الضام. • أظهر الميلاتونين وفيتامين Cفاءة في مو اجهة هذه التغير ات.

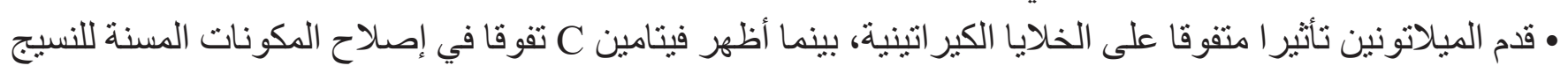
الضام. 